\title{
Spatio-temporal variation of scarab beetles (Coleoptera: Scarabaeidae) in two oak biotopes of Ouled Bechih Forest, Souk-Ahras region (north-eastern Algeria)
}

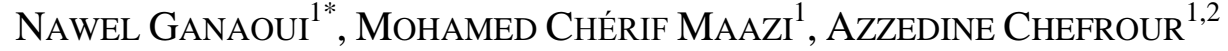 \\ ${ }^{1}$ Laboratory of Aquatic and Terrestrial Ecosystems, Department of Biology, \\ Faculty of Sciences of Nature and Life, Mohamed Cherif Messaadia-Souk Ahras \\ University, Bp 1553, Annaba Road, 41000, Souk Ahras, Algeria \\ ${ }^{2}$ Laboratory for Development and Control of Hospital Pharmaceutical Preparations, \\ Department of Pharmacy, Faculty of Medicine, Badji Mokhtar-Annaba University, \\ 23000, Algeria
}

\begin{abstract}
This paper presents the results of a comparative study with the objective of studying the spatio-temporal variation in the abundance and richness of scarab beetles in two oak biotopes (cork oak - Quercus suber and zeen oak - Q. canariensis) of the Ouled Bechih Forest in the SoukAhras region of north-eastern Algeria during 2017. Two sampling techniques were used: pitfall traps and bidirectional glass traps. During the study period 6022 individuals were collected and 17 species of the family Scarabaeidae were identified. The results of nonparametric tests (MannWhitney U-test and Kruskal-Wallis H-test) show that there is a significant difference in abundance and richness between the two biotopes and from March to August. These two biodiversity parameters were greater in the cork oak than in the zeen oak forests. The activity of the scarab beetles was much higher in the dry season, but lower in the rainy season. The phytophagous species were most influenced by seasonality, especially in the cork oak biotopes, whereas the coprophagous ones remained relatively constant in both habitats.
\end{abstract}

KEY WORDS: Scarabaeidae, spatio-temporal variation, abundance, oak forests.

\footnotetext{
*Corresponding author: ganaoui.nawel@gmail.com
} 


\section{INTRODUCTION}

Mediterranean forests are considered to be complex and rich ecosystems, offering many habitats that host a significant entomological diversity, including beetles, an extremely diverse and important class for forest ecosystems (WIGGINS 1983, FINNAMORE 1996).

Scarabaeoidea are a superfamily of beetles that is widely distributed in ecosystems. With around 20000 species, this superfamily occupies a very important part of forest ecosystems; these many taxa often have very different biological and ecological characteristics, not only in their appearance but also in the diversity of lifestyles, particularly the type of food (BRUSTEL 2000).

Scarabaeidae is a very important family belonging to Scarabaeoidea and includes saproxylic, coprophagous and phytophagous species (BARAUD 1992). Indeed, Scarabaeidae have a diverse diet and are known for their important role in agro-ecosystems: they clear the soil surface of organic waste, either by consuming or burying this more or less deeply into the soil in order to feed themselves or their offspring (HALOTI et al. 2006).

For this reason, several scientists worldwide have been studying the relationship between seasonal fluctuations in diversity and abundance, and biotope diversity (MORAL et al. 2004, Pierre et al. 2008, MAlva et al. 2009, LABruYERE et al. 2016, ADlam et al. 2017).

In Algeria, research on scarab beetles only started recently and these insects are still relatively poorly known in this country. The present study aimed to investigate, for the first time in the Souk Ahras region, the spatial and temporal variability in abundance and species richness of Scarabaeidae in two habitats of cork oak (Quercus suber L.) and zeen oak (Algerian oak) (Q. canariensis WILLD.) in the Ouled Bechih Forest.

\section{MATERIAL AND METHODS}

\section{Study area}

The study was carried out in the Ouled Bechih National Forest, situated in the highlands of eastern Algeria, north of the Souk-Ahras region, near the Tunisian-Algerian border. This forest covers an area of 6582 ha and consists mainly of cork oaks and zeen oaks (Fig. 1). It is characterized by mountainous terrain, a part of the Tellian range, with very steep slopes ranging from $15 \%$ to over $20 \%$. The region has a sub-humid climate, an average annual temperature of $16^{\circ} \mathrm{C}$, an average annual precipitation of $625 \mathrm{~mm}$, and a significant atmospheric humidity $68 \%$ (Fig. 2). 

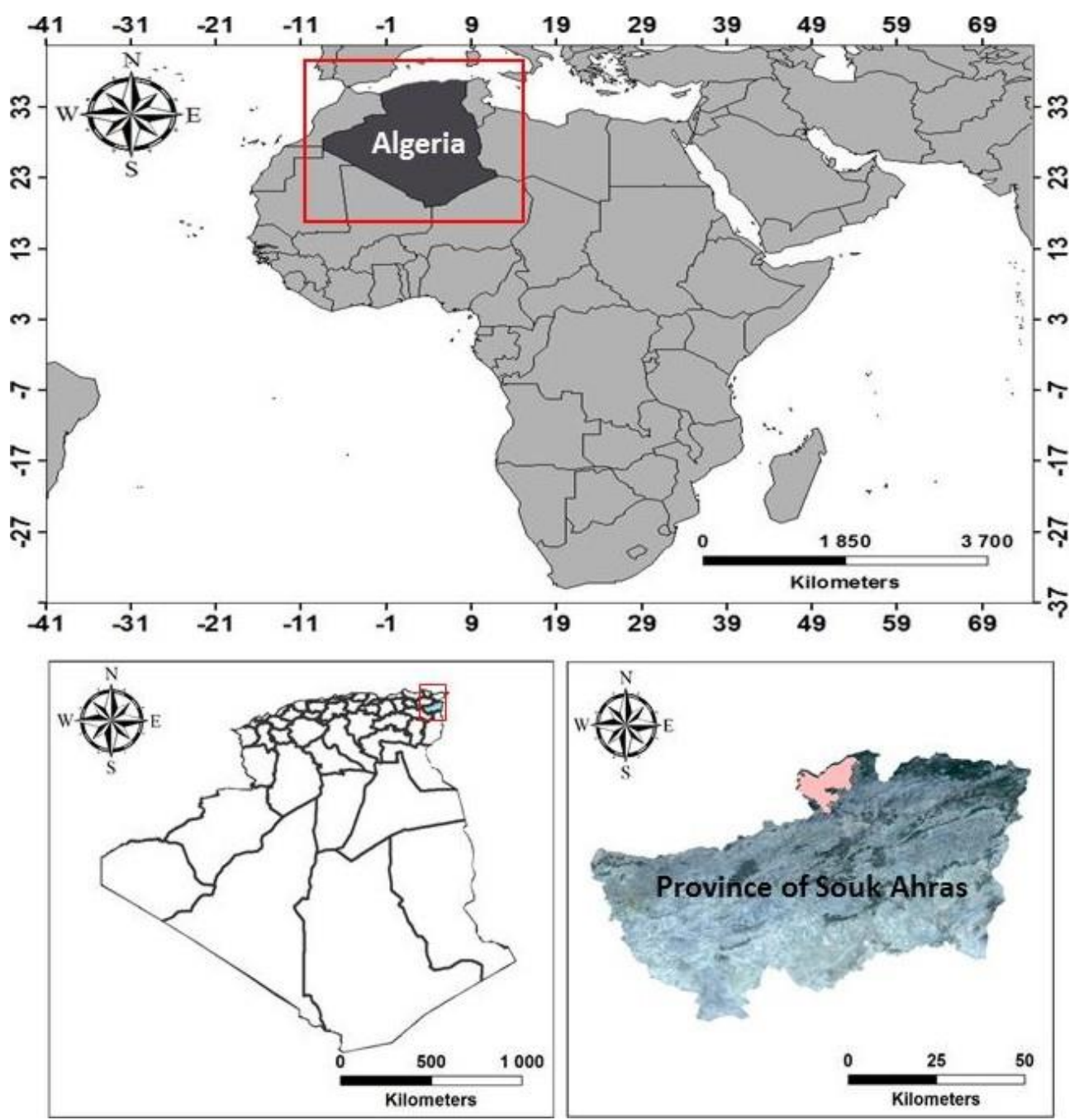

Fig. 1. The study area.

\section{Sampling}

Samples were collected at 20 stations (10 in cork oak forest and 10 in zeen oak forest) (Table 1) from March to October 2017 (Fig. 1), depending on the variation in precipitation and temperature (Fig. 2). 

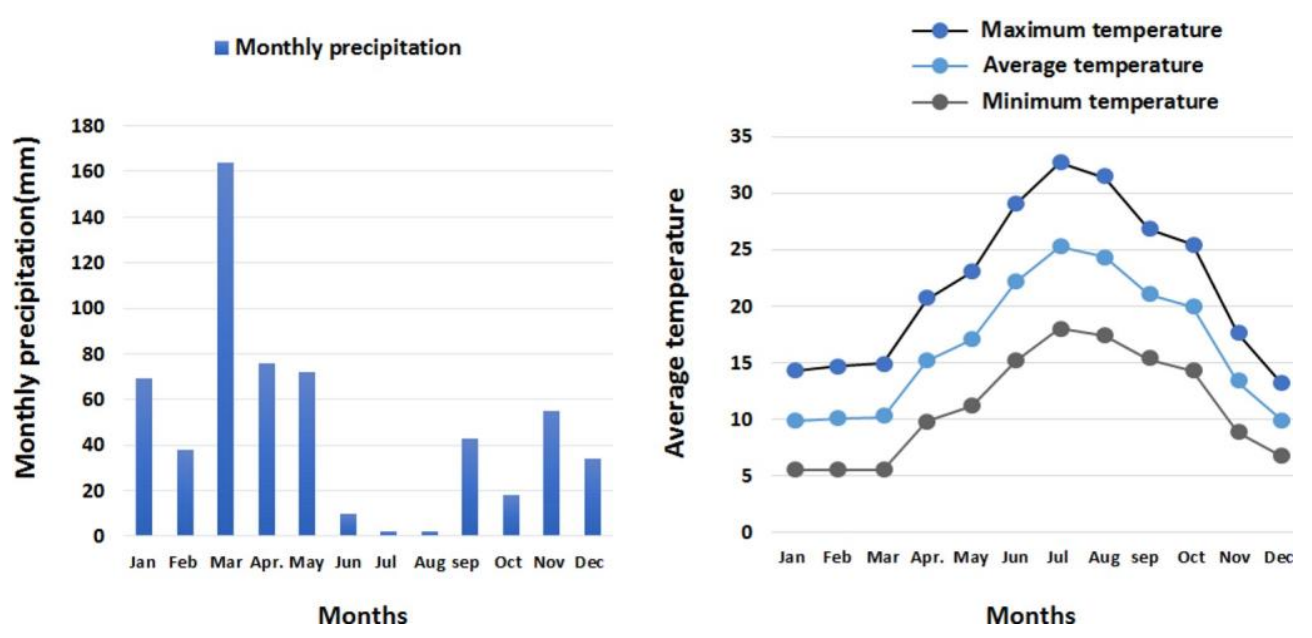

Fig. 2. Variation in temperature and precipitation in the study area during 2017.

Table 1. The geographical positions of the study stations.

\begin{tabular}{|c|c|c|c|c|}
\hline \multirow[t]{2}{*}{ No. of station } & \multirow[t]{2}{*}{ Type of tree } & \multicolumn{3}{|c|}{ Geographical position } \\
\hline & & Latitude & Longitude & Elevation (m) \\
\hline s1 & cork oak & $36^{\circ} 22^{\prime} 03.58^{\prime \prime} \mathrm{N}$ & $7^{\circ} 50^{\prime} 53.92 " \mathrm{E}$ & 826 \\
\hline s2 & cork oak & $36^{\circ} 22^{\prime} 22.62^{\prime \prime} \mathrm{N}$ & $7^{\circ} 50^{\prime} 53.97 " \mathrm{E}$ & 798 \\
\hline s3 & cork oak & $36^{\circ} 22^{\prime} 39.74^{\prime \prime} \mathrm{N}$ & $7^{\circ} 50^{\prime} 53.06 " \mathrm{E}$ & 641 \\
\hline s4 & cork oak & $36^{\circ} 23^{\prime} 34.41^{\prime \prime} \mathrm{N}$ & $7^{\circ} 51^{\prime} 49.90 " \mathrm{E}$ & 890 \\
\hline s5 & cork oak & $36^{\circ} 24^{\prime} 46.55^{\prime \prime} \mathrm{N}$ & $7^{\circ} 55^{\prime} 16.11 " \mathrm{E}$ & 969 \\
\hline s6 & cork oak & $36^{\circ} 21^{\prime} 04.65^{\prime \prime} \mathrm{N}$ & $7^{\circ} 52^{\prime} 11.68 " \mathrm{E}$ & 885 \\
\hline s7 & cork oak & $36^{\circ} 21^{\prime} 16.73 " \mathrm{~N}$ & $7^{\circ} 52 ' 21.03 " \mathrm{E}$ & 844 \\
\hline s8 & cork oak & $36^{\circ} 21^{\prime} 05.01^{\prime \prime} \mathrm{N}$ & $7^{\circ} 52^{\prime} 46.48 " \mathrm{E}$ & 862 \\
\hline s9 & cork oak & $36^{\circ} 21^{\prime} 13.60^{\prime \prime} \mathrm{N}$ & 752'56.74"E & 1094 \\
\hline s10 & cork oak & $36^{\circ} 21^{\prime} 33.38^{\prime \prime} \mathrm{N}$ & $7^{\circ} 53^{\prime} 04.35^{\prime \prime} \mathrm{E}$ & 1080 \\
\hline s11 & zeen oak & $36^{\circ} 22^{\prime} 53.40^{\prime \prime} \mathrm{N}$ & $7^{\circ} 52^{\prime} 28.50 " \mathrm{E}$ & 893 \\
\hline s12 & zeen oak & $36^{\circ} 23^{\prime} 05.14^{\prime \prime} \mathrm{N}$ & $7^{\circ} 533^{\prime} 29.15^{\prime \prime} \mathrm{E}$ & 735 \\
\hline s13 & zeen oak & $36^{\circ} 24^{\prime} 15.40^{\prime \prime} \mathrm{N}$ & $7^{\circ} 54^{\prime} 46.18^{\prime \prime} \mathrm{E}$ & 1066 \\
\hline s14 & zeen oak & $36^{\circ} 23^{\prime} 52.09^{\prime \prime} \mathrm{N}$ & $7^{\circ} 55^{\prime} 32.32 " \mathrm{E}$ & 900 \\
\hline s15 & zeen oak & $36^{\circ} 21^{\prime} 54.26^{\prime \prime} \mathrm{N}$ & $7^{\circ} 53^{\prime} 04.02^{\prime \prime} \mathrm{E}$ & 1038 \\
\hline s16 & zeen oak & $36^{\circ} 21^{\prime} 49.21^{\prime \prime} \mathrm{N}$ & $7^{\circ} 53^{\prime} 30.19^{\prime \prime} \mathrm{E}$ & 972 \\
\hline s17 & zeen oak & $36^{\circ} 21^{\prime} 30.49^{\prime \prime} \mathrm{N}$ & $7^{\circ} 53^{\prime} 42.05^{\prime \prime} \mathrm{E}$ & 912 \\
\hline s18 & zeen oak & $36^{\circ} 21^{\prime} 29.35^{\prime \prime} \mathrm{N}$ & $7^{\circ} 54^{\prime} 13.11 " \mathrm{E}$ & 892 \\
\hline s19 & zeen oak & $36^{\circ} 21^{\prime} 55.76^{\prime \prime} \mathrm{N}$ & $7^{\circ} 54^{\prime} 31.94 " \mathrm{E}$ & 939 \\
\hline s20 & zeen oak & $36^{\circ} 23^{\prime} 14.75^{\prime \prime} \mathrm{N}$ & $7^{\circ} 54^{\prime} 10.53 " \mathrm{E}$ & 866 \\
\hline
\end{tabular}


Pitfall traps and bidirectional glass traps (air traps) were used to collect specimens. The trapping was done with cylindrical metal pots $15 \mathrm{~cm}$ deep and driven into the ground, filled $2 / 3$ with salt water and vinegar. The transect method was used for the installation of traps: five per station were deployed in a line, with the minimum distance between them being fixed at 15 meters. This technique is considered to improve sampling efficiency (HOWDEN \& NEALIS 1975, LOPES et al. 2006) and is more effective at capturing the community of invertebrates that move to the soil surface (MERIGUET \& ZAGATTI 2002). This technique has also proved highly efficient for catching scarab beetles (GARDNER et al. 2008).

The second technique involved 20-liter cans, pierced with small holes to allow rainwater to drain away, which were deployed $1.5 \mathrm{~m}$ above the ground (two traps per station) (BRUSTEL 2001). This technique permits the better sampling of flying species (TOUROULT 2017).

\section{Preparation and identification of specimens}

Large specimens were identified on site. The remainder were preserved in $70 \%$ alcohol and identified in the laboratory under a compound binocular microscope (EZ4, LEICA) with the aid of keys (LERAUT 2013, MALDANER et al. 2015).

The specimens were also compared with the specimens in the collection from the Museum of the Algerian National Institute of Plant Protection (INPV). Some species were identified by specialists: Doumadji SAlaEdDINE (ENSA Algeria) and GuY CHAVANON (University of Ouejda, Morocco).

\section{Data analysis}

Diversity indices such as total abundance, species richness, the Shannon-Weaver index and the equitability index "E" (SHANNON \& WEAVER 1949) were used to compare the diversity and the degree of community complexity of Scarabaeidae species in the cork oak and zeen oak biotopes. The non-normality of the data was confirmed with the Shapiro-Wilk test (SHAPIRO \& WILK 1965). In addition, two nonparametric tests were performed: the Mann-Whitney U-Test to compare the richness and abundance between the two biotopes and the Kruskal-Wallis H-Test to compare the same indices during each month. The effect of seasonal variations and habitat preferences of scarab beetles were subjected to Correspondence Factorial Analysis (CFA). All the data were analyzed using XLSTAT software. 


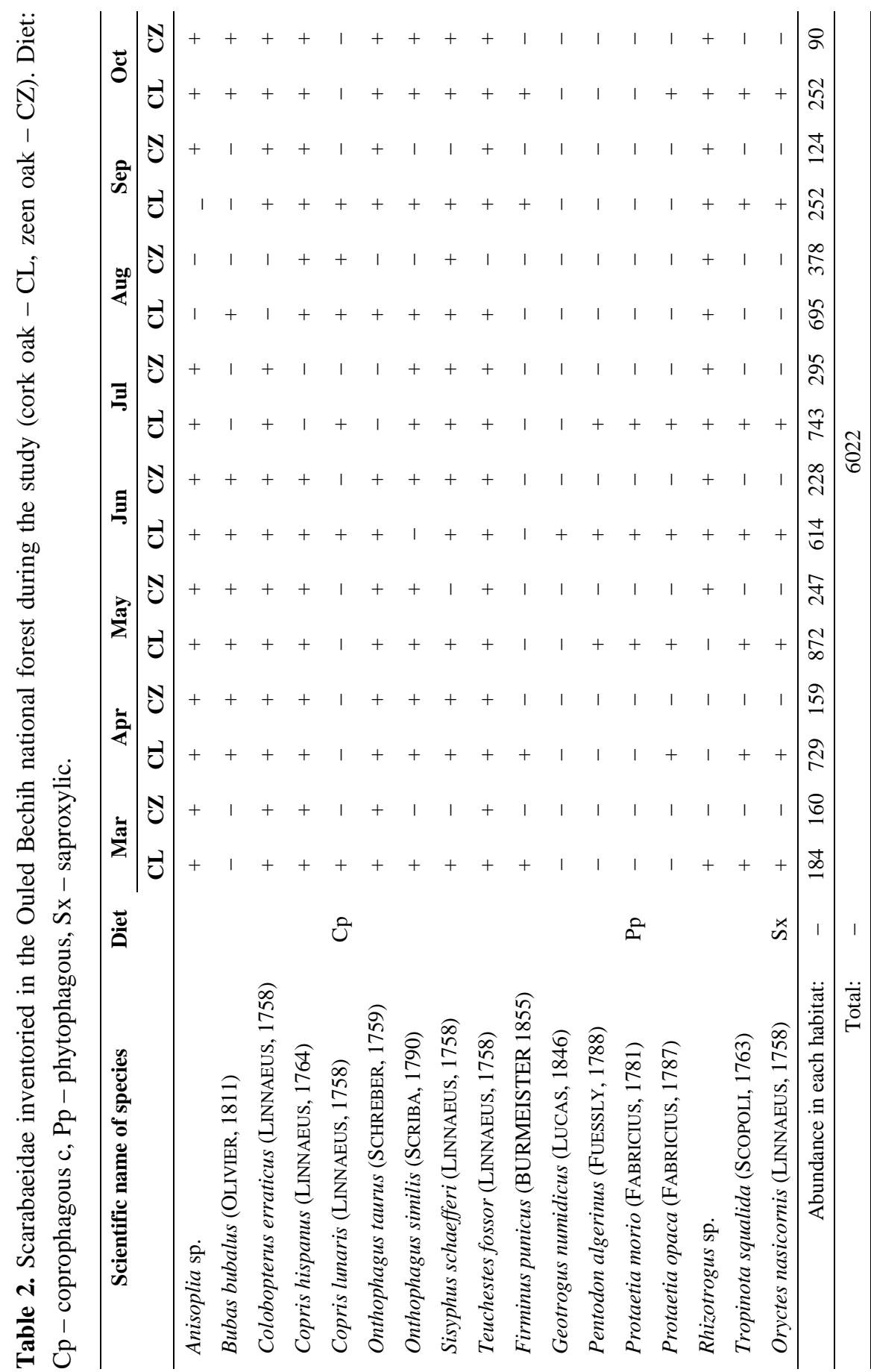




\section{RESULTS}

A total of 6022 individual scarab beetles from 17 species were recorded, including 7 phytophagous, 9 coprophagous and 1 saproxylic ones, in 8 monthly samples (Table 2). The highest number of species were collected in June ( 9 species) in the cork oak biotopes, and the lowest number in October (3 species) (Fig. 3a).
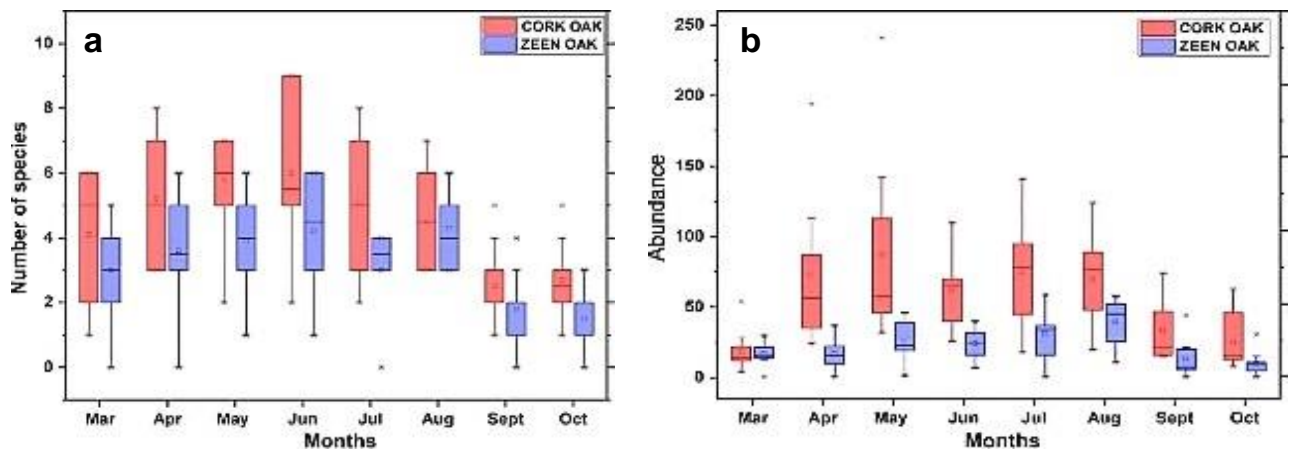

Fig. 3. The monthly fluctuation of a) species richness and b) abundance of scarab beetles between the cork oak and zeen oak biotopes during the study period.

The 6022 individuals were distributed as follows: 4341 in cork oak and 1681 in zeen oak (Table 1). The dominant species as defined by abundance in the two biotopes were Copris hispanus (1221 individuals), Sisyphus schaefferi (1205), Teuchestes fossor (838) and Onthophagus taurus (600).

The highest number of individuals was recorded in cork oak in August (226 individuals) and in zeen oak in May (115). The fewest individuals were recorded in zeen oak in March (12 individuals) and in cork oak in October (70) (Fig. 3b).

Five phytophagous species (Firminus punicus, Rhizotrogus sp., Protaetia morio, $P$. opaca and Tropinota squalida) and one saproxylic species (Oryctes nasicornis) were recorded only in cork oak. The highest abundance was recorded in late spring and early summer. Oryctes nasicornis was abundant from March to August; its numbers peaked in August (27 individuals).

The coprophagous beetles were the most abundant in spring and summer, subsequently decreasing in number in September and October. There were 123 and 116 individuals of $O$. similis and Teuchestes fossor respectively in April, 318 of Sisyphus schaefferi in May, and 216 and 114 of Copris hispanus and Onthophagus taurus respectively in June (Fig. 4). The 

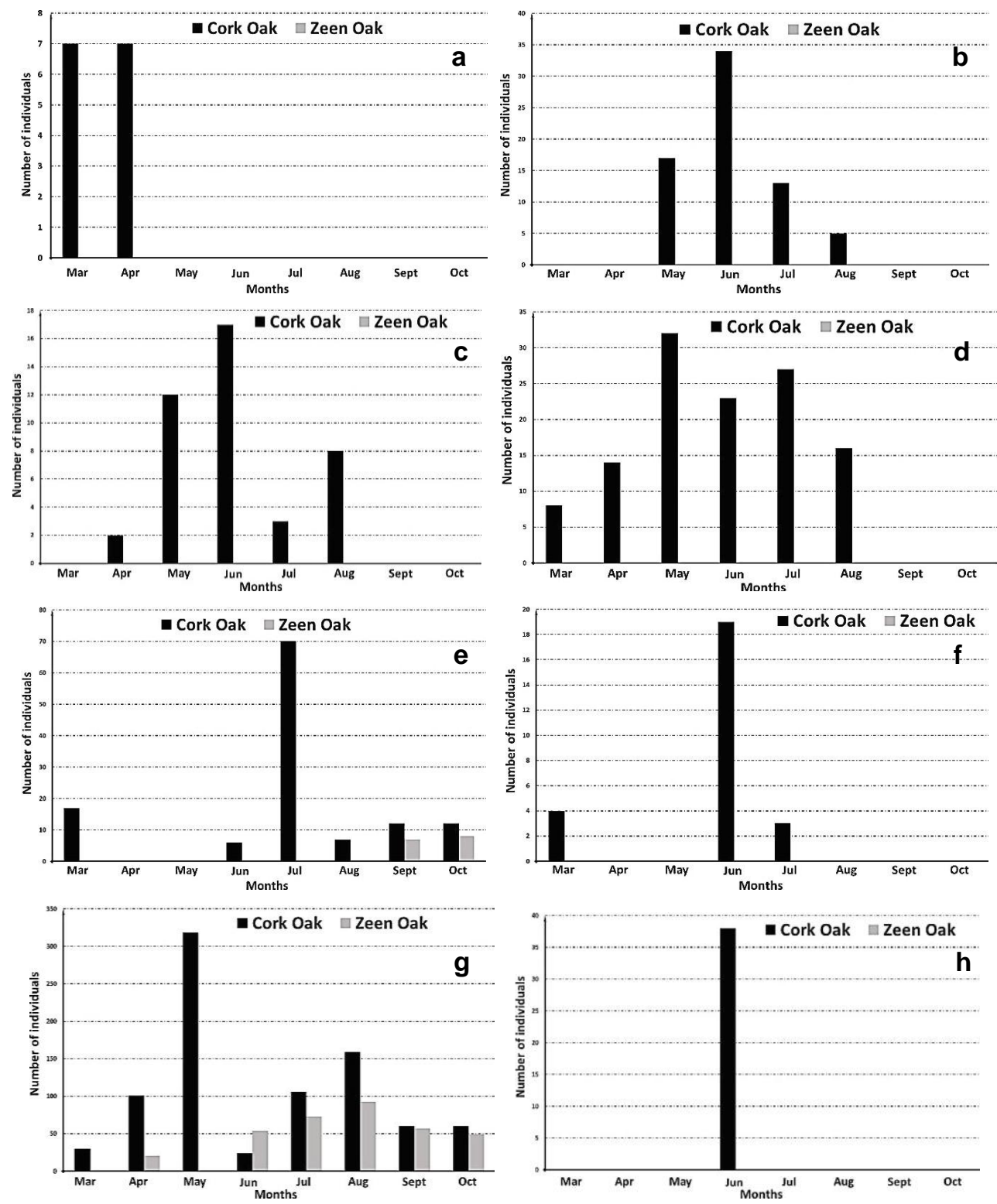

Fig. 4. Activity of scarab beetle species collected between March and October (2017). Firminus punicus (a), Protaetia morio (b), P. opaca (c), Tropinota squalida (d), Bubas bubalus (e), Pentodon algerinus (f), Sisyphus schaefferi (g), Rhizotrogus sp. (h). 

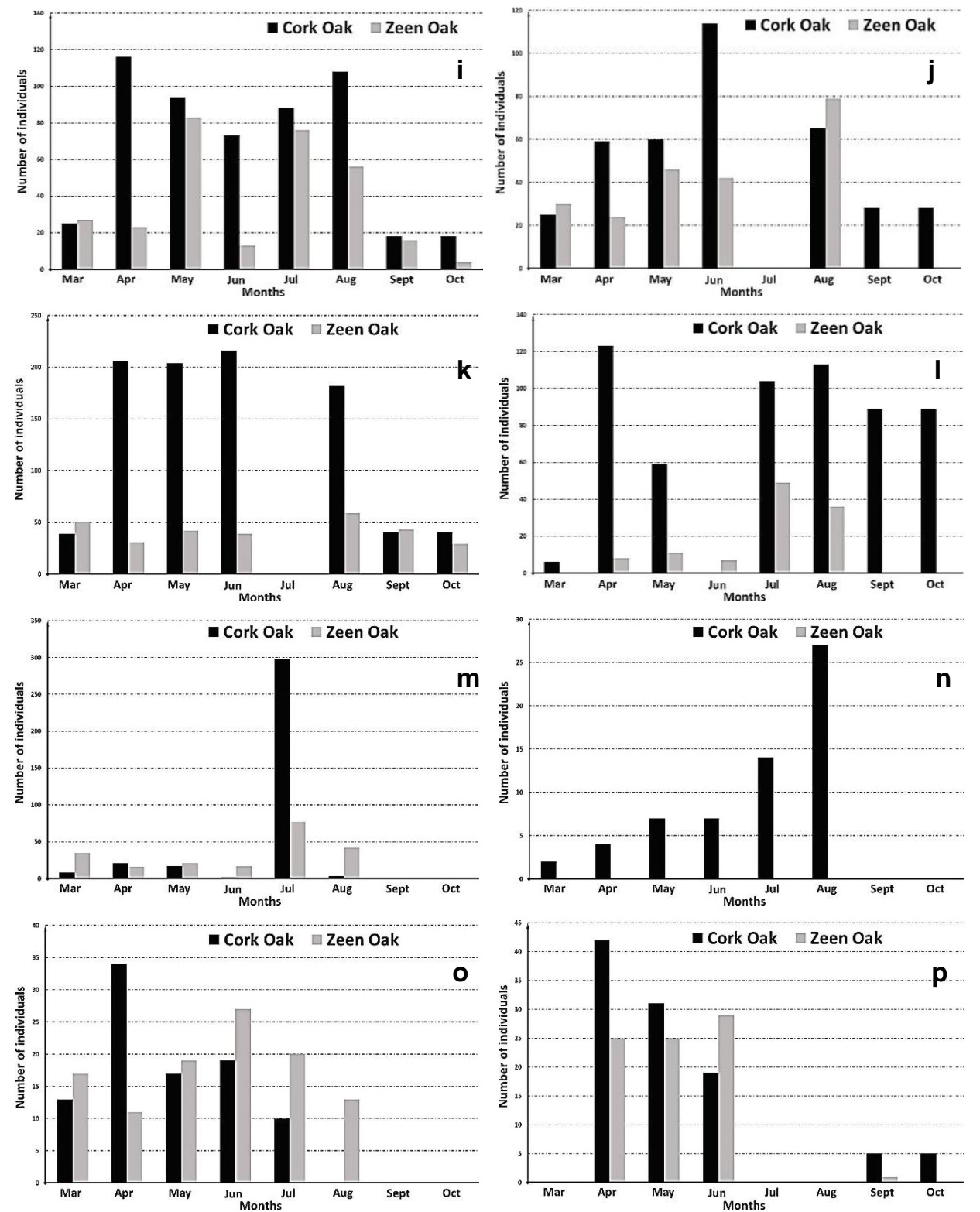

Fig. 4. Continued. Copris hispanus (i), Onthophagus taurus (j), Copris hispanus (k), Onthophagus similis (l), Anisoplia sp. (m), Oryctes nasicornis (n), Colobopterus erraticus (o), Bubas bubalus (p). 


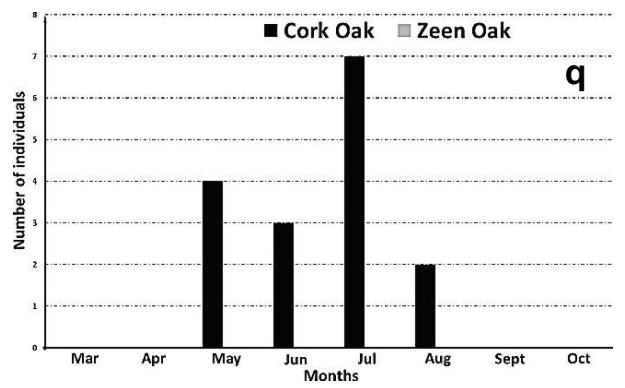

Fig. 4. Continued. Geotrogus numidicus (q).
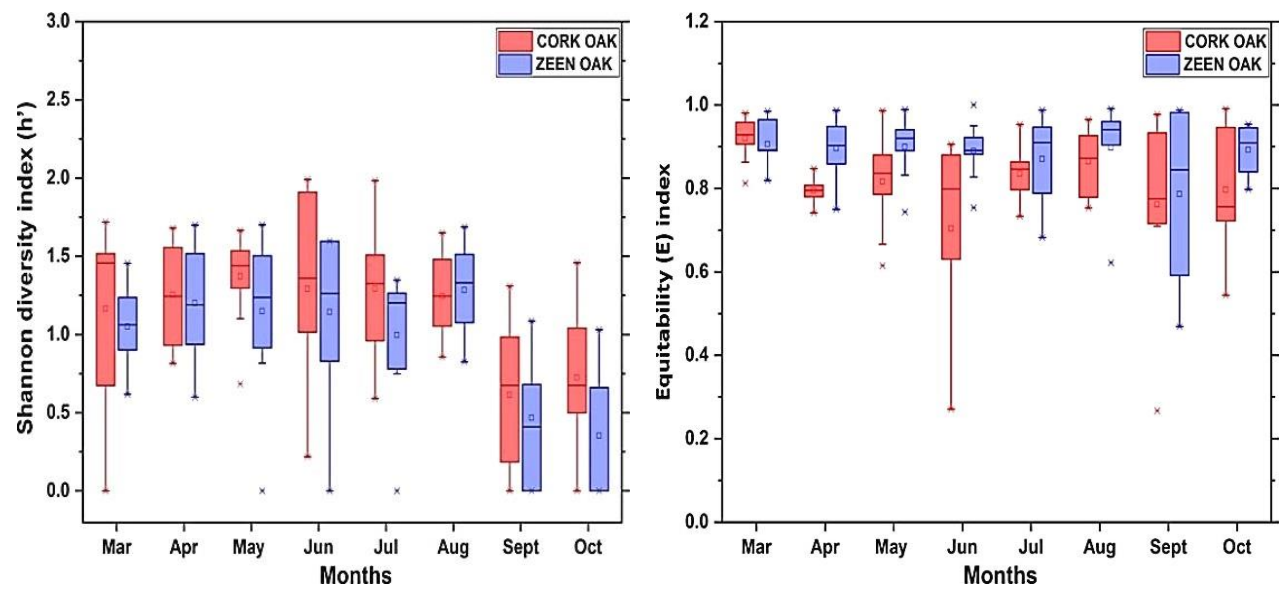

Fig. 5. Shannon-Weaver monthly index and equitability fluctuation of scarab beetles between the cork oak and zeen oak biotopes during the study period.

other species were active throughout the 8 months and in both biotopes, with remarkable variations between the months: their activity was lower in October and September and higher between April and June.

The minimum value of the Shannon-Weaver diversity index $\left(\mathrm{H}^{\prime}\right)$ was recorded in zeen oak (1.1 bits) during October and the maximum value was recorded in cork oak (2 bits) in June (Fig. 5a).

The index of equitability "E" was always close to 1 between 0.80 and 0.98 bits. The maximum was recorded in zeen oak ( 0.98 bits) during September and the minimum (0.80) at the cork oak stations during June (Fig. 5b).

The Mann-Whitney U-test indicated a significant difference $(P<0.001)$ in the richness and abundance of Scarabaeidae species between the two cork oak and zeen oak biotopes (Table 3). 
Table 3. Results of the Mann-Whitney U-test of scarab beetles (abundance and richness).

\begin{tabular}{|c|c|c|c|c|}
\hline \multirow{3}{*}{ 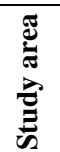 } & \multicolumn{4}{|c|}{ Mann-Whitney U-test (between two biotopes) } \\
\hline & \multicolumn{2}{|c|}{ Abundance } & \multicolumn{2}{|c|}{ Richness } \\
\hline & $\mathrm{U}=1403.5$ & $P<0.001$ & $\mathrm{U}=2015.0$ & $P<0.001$ \\
\hline
\end{tabular}

The results of the CFA showed that the species were subdivided into three main groups, which could be found on the factorial plane of the F1 and F2 axes. The first two axes (F1 and F2) defined the main plane of the analysis and represent $61.92 \%$ of the information. The F1 axis provides $42.93 \%$ and the F2 axis provides $18.99 \%$ of the total inertia of the data (Table 4).

Table 4. Results of the Kruskal-Wallis H-test of scarab beetles (abundance and richness).

\begin{tabular}{lllll}
\hline \multicolumn{4}{c}{ Kruskal-Wallis H-test (between months) } \\
\hline \multicolumn{3}{c}{ Abundance } & \multicolumn{2}{c}{ Richness } \\
\hline Cork oak & $\mathrm{H}=36.16$ & $P<0.001$ & $\mathrm{H}=28.23$ & $P<0.001$ \\
Zeen oak & $\mathrm{H}=27.80$ & $P=0.001$ & $\mathrm{H}=27.28$ & $P=0.001$ \\
\hline
\end{tabular}

Table 5a and Fig. 6 and show that Anisoplia sp., Colobopterus erraticus, Copris hispanus, C. lunaris, Teuchestes fossor, Bubas bubalus, Onthophagus taurus, Sisyphus schaefferi and Pentodon algerinus are well represented by the axes F1 and F2.

Table 5. Cosine squares (\%) of species and months with two biotopes.

\begin{tabular}{lccc}
\hline & & $\operatorname{Cos}^{\mathbf{2}}(\boldsymbol{\%})$ & \\
\hline a) Species & F1 & F2 & F1+F2 \\
\hline Firminus punicus & 2.89 & 0.84 & 3.73 \\
Protaetia morio & 0.85 & 10.32 & 11.18 \\
Protaetia opaca & 14.67 & 11.34 & 26.02 \\
Tropinota squalida & 1.36 & 29.16 & 30.52 \\
Copris lunaris & 42.52 & 30.38 & $\mathbf{7 2 . 9 0}$ \\
Rhizotrogus sp. & 3.78 & 4.03 & 7.81 \\
Sisyphus schaefferi & 14.82 & 38.62 & $\mathbf{5 3 . 4 4}$ \\
Geotrogus numidicus & 9.86 & 1.09 & 10.95 \\
\hline
\end{tabular}


Table 5. Continued.

\begin{tabular}{|c|c|c|c|}
\hline & & $\operatorname{Cos}^{2}(\%$ & \\
\hline a) Species & F1 & F2 & $\mathbf{F} 1+\mathbf{F} 2$ \\
\hline Teuchestes fossor & 4.68 & 59.19 & 63.87 \\
\hline Onthophagus taurus & 28.18 & 31.65 & 59.84 \\
\hline Copris hispanus & 78.96 & 0.47 & 79.44 \\
\hline Onthophagus similis & 0.89 & 12.76 & 13.65 \\
\hline Anisoplia sp. & 97.50 & 0.66 & 98.16 \\
\hline Oryctes nasicornis & 1.12 & 17.32 & 18.44 \\
\hline Colobopterus erraticus & 0.94 & 79.55 & 80.49 \\
\hline Bubas bubalus & 5.86 & $\mathbf{5 7 . 4 3}$ & 63.29 \\
\hline a) Species & F1 & F2 & F1+F2 \\
\hline Pentodon algerinus & 32.37 & 20.13 & 52.49 \\
\hline b) Stations (months) & F1 & F2 & $\mathbf{F} 1+\mathrm{F} 2$ \\
\hline Cork (Mar) & 7.39 & 10.26 & 17.65 \\
\hline Zeen (Mar) & 7.10 & 40.61 & 47.70 \\
\hline Cork (Apr) & 38.98 & 4.49 & 43.46 \\
\hline Zeen (Apr) & 0.52 & 66.26 & 66.78 \\
\hline Cork (May) & 34.96 & 9.07 & 44.03 \\
\hline Zeen (May) & 0.00 & 88,18 & 88.18 \\
\hline Cork (Jun) & 27.44 & 1.34 & 28.79 \\
\hline Zeen (Jun) & 1.28 & 86.93 & 88.21 \\
\hline Cork (Jul) & 94.09 & 3.94 & 98.02 \\
\hline Zeen (Jul) & 57.08 & 3.89 & 60.97 \\
\hline Cork (Aug) & 24.66 & 13.98 & 38.64 \\
\hline Zeen (Aug) & 0.36 & 66.11 & 66.46 \\
\hline Cork (Sept) & 9.35 & 19.91 & 29.26 \\
\hline Zeen (Sept) & 12.51 & 18.98 & 31.49 \\
\hline Cork (Oct) & 3.26 & 14.34 & 17.60 \\
\hline Zeen (Oct) & 6.35 & 33.73 & 40.09 \\
\hline
\end{tabular}

These species have very high square cosine values in the factorial planes F1and F2, varying from $52.49 \%$ to $98.16 \%$. The other species are close to the origin and have weak square cosine values, between $3.73 \%$ and $30.52 \%$, because they are less well represented by the two axes (F1 and F2) (Table 6). The first axis isolates two species: Anisoplia sp. and 
Copris hispanus. This group characterizes species with high activity in both zeen oak and cork oak biotopes in July: they have square cosine values of $57.08 \%$ and $94.09 \%$ respectively (Table 5b). The second axis isolates three species: Bubas bubalus, Teuchestes fossor and Colobopterus erraticus. This group characterizes species with high activity at zeen oak stations in April, May, June and August (spring and summer): they have respective square cosine values of $66.11 \%, 66.26 \%, 86.93 \%$ and $88.18 \%$ (Table $5 b$ ).

\section{DISCUSSION}

The present study Involved a monthly survey of the Scarabaeidae distribution in two biotopes (cork oak and zeen oak) in the Ouled Bechih Forest. Comparison of the species richness between the two biotopes showed that the cork oak biotope accommodated the greatest species richness. Phytophagous species were observed more frequently at the cork oak stations than at the zeen oak stations. The cork oak biotope is associated with an important plant diversity composed mainly of Calicotome spinosa (L.), Erica arborea L., Leucanthemum vulgare LAM., Eryngium tricuspidatum L., Asphodelus ramosus L. and Anacyclus clavatus (DESF.), which could form a favorable environment for phytophages because of the availability of food resources for their development.

There were highly significant fluctuations in species richness in both biotopes $(P<0.001)$ between months. This outstanding difference is caused by variations in climatic factors such as temperature and precipitation, which can influence the distribution of species (FEER \& CERDAN 2006). The species that manifested high activity levels during the flowering period (spring) were the phytophagous Scarabaeidae such as Protaetia morio, $P$. opaca and Tropinota squalida. This was also found by LAWRENCE \& BRITTON (1994), who mentioned that these species feed primarily on flowers; this result is also consistent with that obtained by SoutHWOOD et al. (1979) and TILMAN et al. (1997), who also explained that the diversity of phytophages is motivated by the plant diversity at the stations. The numbers of individuals caught during the study period indicate that the diversity of Scarabaeidae is higher in the cork oak forest, which favors the development of beetles in that fecal matter is available.

Indeed, feces are the essential food source for coprophagous species, which are known as bioindicators of grazing activity, widespread in the cork forests of north-eastern Algeria. These types of species contribute greatly to improving soil quality through recycling. This was observed by JULIEN et al. (2017), who indicated that the abundance of coprophagous insects was the highest in feces. 

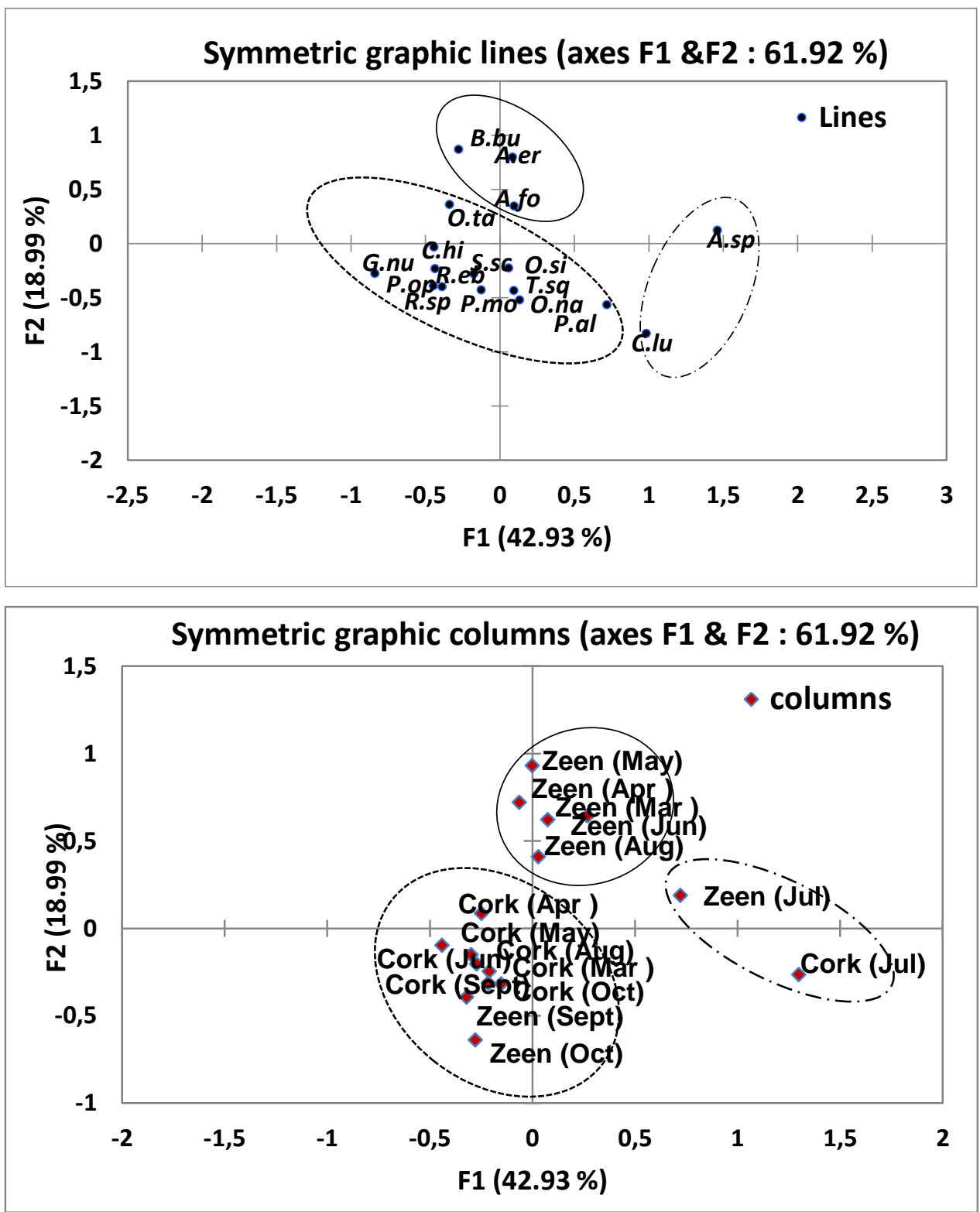

Fig. 6. Factorial Analysis $1 * 2$ of Correspondence Factor Analysis (CFA) of scarab beetles. A.sp. - Anisoplia sp., B.bu - Bubas bubalus, C.er - Colobopterus erraticus, C.hi - Copris hispanus, C.lu - Copris lunaris, O.ta - Onthophagus taurus, O.si - Onthophagus similis, S.sc - Sisyphus schaefferi, T.fo - Teuchestes fossor, F.pu - Firminus punicus, G.eo Geotrogus numidicus, P.al - Pentodon algerinus, P.mo - Protaetia morio, P.op - Protaetia opaca, R.sp. - Rhizotrogus sp., T.sq - Tropinota squalida, O.na-Oryctes nasicornis. 
Table 6. Eigenvalues and percentages of inertia of scarab beetles on the two axes (F1, F2).

\begin{tabular}{cccc}
\hline Axes & Eigenvalues & Inertia $(\boldsymbol{\%})$ & \% cumulated \\
\hline F1 & 0.276 & 42.93 & 42.93 \\
F2 & 0.122 & 18.988 & 61.919 \\
\hline
\end{tabular}

The variation in the abundance of Scarabaeidae between months was highly significant $(P<0.001)$. This was probably due to the variations in the weather conditions in each month, which act on the distribution and the activity of the species. The decrease in the scarab beetle abundance in September and October can be explained by the disappearance of leaves in this period, a major cause of the disappearance of the soil fauna (BORGES et al. 2005).

Our results showed an increase in abundance during the summer, in contrast to the study of HALFFTER \& MATTHEws (1966), who explained the decrease in abundance by the decrease in humidity and high air temperatures, which affect the nutritional value and availability of food for Scarabaeidae. Climatic factors effectively determine and largely influence the activity of insects and their development. With regard to the monthly monitoring of species abundance, most Scarabaeidae are active in spring and early summer in both biotopes, in which the most dominant species are Copris hispanus, Sisyphus schaefferi, Onthophagus similis and O. taurus; this tallies with the results of CARPANETO et al. (2007). Several studies have shown that Sisyphus schaefferi is not limited to forest environments but prefers hard, dry soils and avoids sands and cultivated land (PAULIAN \& BARAUD 1982). These species are attracted by the food and not necessarily the biotope of oak, their preferred food resource being the excrement of sheep and goats (SCHMELTZ \& GANGLOFF 2012). These results are similar to those reported by HALOTI et al. (2006) and El Aichar et al. (2013).

Onthophagus taurus and $O$. similis are persistent species, encountered throughout the study period. The genus Onthophagus is highly adaptable to different climates. However, these two species are sensitive to variations in food resources and not to climatic variations, a fact mentioned by CARPANETO et al. (2005).

Teuchestes fossor is also active throughout the year. It reproduces during the cool and wet periods of the year, and larval development depends on small-sized feces. Its abundance was the highest at the end of the summer. Similar results were reported by FinN et al. (1999), a study which also revealed an increase in the number of T. fossor.

Shannon-Weaver indices were higher in the cork oak biotope: this is therefore more diverse and offers a greater number of trophic resources. The study environment seems to be balanced and the species are distributed equally among the two biotopes. This was demonstrated by the equitability values, which were close to 1 : a value of "E" approaching 
1 reflects a rather stable distribution, +but when $\mathrm{E}$ approaches 0 , this illustrates a hierarchical abundance that reflects a simple environment (DAJOZ 1971).

The difference in the diversity of Scarabaeidae between seasons and both biotopes was also demonstrated by Correspondence Factorial Analysis (CFA), which revealed a clear distinction between the dry and wet seasons. The first group includes species that demonstrated heightened activity in July in both biotopes (Anisoplia sp. and Copris hispanus). The second group emphasizes high levels of activity in the zeen oak among coprophagous species such as Onthophagus taurus, Colobopterus erraticus, Teuchestes fossor and Bubas bubalus, since there is not much plant cover; moreover, because there is less interspecific competition, the coprophagous species can increase their activity in the zeen oak. The third group includes the species that prefer the cork oak in the period from March to August; this group is dominated by phytophagous Scarabaeidae such as Protaetia morio, P. opaca, Rhizotrogus sp. and Tropinota squalida, which prefer to congregate in spring in a very varied plant cover, as demonstrated by BouKLI et al. (2014). In addition, we also recorded coprophagous species such as Sisyphus schaefferi, Onthophagus similis and Copris hispanus, which share the same food sources.

During autumn, there is a drop in the overall activity of these species, including the phytophagous Scarabaeidae, which shows that there is seasonal and spatial segregation within this family. These results are also supported by the studies of EL AICHAR et al. (2014) in the El Kal region and by ERRouissi et al. $(2009,2011)$ in Tunisia.

\section{CONCLUSION}

This study aimed to evaluate the ecological diversity of Scarabaeidae in two oak environments (cork oak and zeen oak) and to test the influence of seasonal variations on their abundance and species richness. The species diversity of Scarabaeidae is greater in the cork oak forest than in the zeen oak forest. This diversity varied significantly with variation in climatic factors. Phytophagous species are more affected by seasonality and environmental variation than coprophagous ones which, in turn, are influenced much more by food resources. The Ouled Bechih Forest is an ideal ecosystem for the development of the majority of Scarabaeidae. The present study covered only one family of beetles, however. It would be interesting to get to know other families that are associated with other forest formations. To date, there have been only a few studies of Scarabaeidae in the SoukAhras region. Through this article we hope to draw the attention of researchers to the importance of these species in the functioning of forest ecosystems. 


\section{ACKNOWLEDGEMENTS}

The authors extend their thanks to Mr. El Hadi GanaOUI and Mr. Adem GanaOUI for their availability during the installation of the traps and their strong contributions to the inventory of scarabs. We thank also the editor and the anonymous reviewers for their help in finding lapses and errors, which improved the manuscript.

\section{REFERENCES}

Adlam C., Despland E., Beaulieu F. 2017. Spatial and temporal patterns of ground beetle (Coleoptera: Carabidae) activity across habitats at the Mont St. Hilaire Biosphere Reserve, Quebec. The Journal of the Entomological Society of Ontario, 148: 23-28.

Aichar M.E., Labidi I., Benyacoub S. 2013. Dung Beetles (Coleoptera: Scarabaeidae) Community Composition in El Kala National Park (North-Eastern Algeria). European Journal of Scientific Research, 108 (1): 2-37.

AICHAR Mr.E. 2014. Composition and organization of the settlement scarabaides dung in northeastern Algeria: occupation of space and ecological role. PhD Thesis, Badji Mokhtar University, Annaba.

BARAUD J. 1992. Faune de France et régions limitrophes, 78. Coleopteres Scarabaeoidea d'Europe. Fédération française des Sociétés de Sciences naturelles et Société linnéenne de Lyon, Paris Cedex - Lyon.

Bebermans J., FAGOT J., Francis F. 2016. Contribution à l'écologie des coléoptères coprophiles et coprophages en Belgique: diversité spécifique, préférences stercorales et phénologie. Faunistic Entomology, 69: 125-138.

Borges A., Meriguet B., Zagatti P. 2005. Parcs départementaux de Seine-Saint-Denis: Parc de la Courneuve, Parc du Sausset, Parc de la Haute Île, Parc de l'Île-Saint-Denis, Parc Jean Moulin Les Guillands De La Courneuve, Parc Du Sausset. Inventaire Entomologique 2005. Seine-SaintDenis Conseil Général, Bobigny.

Boudy P. 1955. Économie forestière nord-africaine: Description forestière de l'Algérie et de la Tunisie. P. Boudy, Larose.

Boukli S.H, Abdellaoui K., Ponel P., Chaoui B.C, Bettioui R. 2014. Analyses de la structure fonctionnelle des peuplements de Coléoptères dans le marais estuarien de la Tafna (Algérie). Bulletin de la Societe Zoologique de France, 139 (1-4): 5-19.

Brustel H., Clary J. 2000. Oh, this Grésigne! Outstanding achievements for this forest and for the South West of France: faunistical data and conservation prospects (Coleoptera): supplement to the Jean Rabil catalogue, 1992, 1995. Bulletin de la Société Entomologique de France, 105 (4): 357-374.

BRUSTEL S. 2001. Coléoptères saproxyliques et valeur biologique des forêts françaises. $\mathrm{PhD}$ thesis, Institut National Polytechnique de Toulouse, Toulouse.

Carpaneto A., Geiger D., Bamberg E., Sauer N., Fromm J., Hedrich R. 2005. Phloem-localized, proton-coupled sucrose carrier ZmSUT1 mediates sucrose efflux under the control of the sucrose gradient and the proton motive force. Journal of Biological Chemistry, 280 (22): 21437-21443. 
Carpaneto G.M., Mazziotta A., Valerio L. 2007. Inferring species decline from collection records: Roller dung beetles in Italy (Coleoptera, Scarabaeidae). Diversity and Distributions, 13 (6): 903-919.

DAJOZ R. 1971. Precis of ecology. Dunod, Paris.

ERrouissi F., LABidi I., JAY-Robert P., NOUÏRA S., Lumaret J.P. 2011. Dung beetle assemblage's organization in two contrasted areas of the Mediterranean region: affinities and divergences. Annales de la Société Entomologique de France, 47 (3-4): 402 -417.

ERROUISSI F., LABIDI I., NOUIRA S. 2009. Seasonal occurrence and local coexistence within scarabaeid dung beetle guilds (Coleoptera: Scarabaeoidea) in Tunisian pasture. European Journal of Entomology, 106 (1): 85-94.

FEER F., CERDAN P. 2006. Variations saisonnières d'activité dans un assemblage de coléoptères nécrophages (Coleoptera, Scarabaeidae) en forêt tropicale humide. Revue d'Écologie (Terre Vie), 61 (3): 247-260.

FinN J.A., GitTingS T., GiLLER P.S. 1999. Spatial and temporal variation in species composition of dung beetle assemblages in southern Ireland. Ecological Entomology, 24 (1): 24-36.

FinNAMORE A.T. 1996. The advantages of using arthropods in ecosystem management. A brief from the Biological Survey of Canada (Terrestrial Arthropods). Biological Survey of Canada (Terrestrial Arthropods), Ottawa.

Gardner T.A., Barlow J., Araujo I.S., Ávila-Pires T.C., Bonaldo A.B., Costa J.E., Esposito M.C., Ferreira L.V., Hawes J., Hernandez M.I., Hoogmoed M.S. 2008. The cost-effectiveness of biodiversity surveys in tropical forests. Ecology Letters, 11 (2): 139-150.

HALFfer G. MAtTHEws E.G. 1966. The natural history of dung beetles of the subfamily Scarabaeinae (Coleoptera, Scarabaeidae). Folia Entomologica Mexicana, 12-14: 1-312.

Haloti S., Janati-Idrissi A., Chergui H., Lumaret J.P. 2006. Structure des communautes de Scarabeides coprophages du Maroc nord-occidental (Coleoptera, Scarabaeoidea). Bulletin de l'Institut Scientifique, Rabat (Maroc), 28: 25-34.

HeRnANDEZ M.I.M., VAZ-De-Mello F.Z. 2009. Seasonal and spatial species richness variation of dung beetle (Coleoptera, Scarabaeidae s. str.) in the Atlantic Forest of southeastern Brazil. Revista Brasileira de Entomologia, 53 (4): 607-613.

Howden H.F., NEALIS V. 1975. Effects of clearing in a tropical rain forest on the composition of the coprophagous scarab beetle fauna (Coleoptera). Biotropica, 7 (2): 77-83.

Labruyere S., Bohan D.A., Biju-Duval L., Ricci B., Petit S. 2016. Local, neighbor and landscape effects on the abundance of weed seed-eating carabids in arable fields: A nationwide analysis. Basic and Applied Ecology, 17 (3): 230-239.

Lawrence J.F., Britton E.B., 1994. Australian Beetles. Melbourne University Press, Carlton.

LERAUT P. 2013. Espèces et genres nouveaux de Pyralinae (Lepidoptera, Pyraloidea, Pyralidae). Bulletin de la Société Entomologique de France 118 (1):41-72.

LOPES P.P., LOUZADA J.N.C., VAZ-De-Mello F.Z. 2006. Organization of dung beetle communities (Coleoptera, Scarabaeidae) in areas of vegetation re-establishment in Feira de Santana, Bahia, Brazil. Sitientibus Série Ciências Biológicas, 6 (4): 261-266. 
Maldaner M.E., Nunes R.V., VaZ-De-Mello F.Z. 2015. Taxonomic revision of the Dichotomius speciosus (WATERHOUSE, 1891) species group (Coleoptera: Scarabaeidae: Scarabaeinae). Zootaxa, 3986 (5): 549-560.

Meriguet B., Zagatti P. 2002. Inventaire entomologique de la forêt régionale de Galuis (Yvelines Val d'Oise). Office pour les insectes et leurs environnements. Internet: http://www.insectes.org/ opie/pdf/377_pagesdynadocs47fcd2728dfef.pdf

Mora F., Albignac R., Robert J.C., Cretin J.Y., Prouteau C., Robert J.Y. 2004. La structure spatiale et temporelle de l'entomofaune circulante comme indicateur biologique dans la gestion des forêts et des prairies. Revue d'Écologie (Terre Vie), 59 (2): 229-241.

Paulian R., Baraud J. 1982. Faune des coleopteres de France. II. Lucanoidea and Scarabaeoidea. Editions Lechevalier S.A.R.L., Paris.

Pierre J.R., Jean-Pierre L., JeAn-Dominique L. 2008. Spatial and Temporal Variation of Mountain Dung Beetle Assemblages and Their Relationships with Environmental Factors (Aphodiinae: Geotrupinae: Scarabaeinae). Ecology and population biology. Annals of the Entomological Society of America, 101 (1): 58-69.

Schmeltz B., GANGloff L. 2012. Sisyphus schaefferi (LINNAEUS, 1758) (Coleoptera, Scarabaeidae) on the Rhine Island: the return to Alsace? Conservation measures of the coprophagous entomofauna of the National Nature Reserve of the Alsatian Little Camargue: Bulletin de la Société Entomologique de Mulhouse, 68 (1): 1-6.

SHANNON C.E., WEAVER W. 1949. The mathematical theory of communication. University of Illinois Press, Urbana.

SHAPIRO S.S., WiLK M.B. 1965. An analysis of variance test for normality (complete samples). Biometrika, 52 (3/4): 591-611.

SOUTHwoOd T.R., Brown V.K., READER P.M. 1979. The relationships of plant and insect diversities in succession. Biological Journal of the Linnean Society, 12 (4): 327-348.

Tilman D., Knops J., Wedin D., Reich P., Ritchie M., Siemann E. 1997. The influence of functional diversity and composition on ecosystem processes. Science, 277 (5530): 1300-1302.

Touroult J., Poirier E., Mill N., Deknuydt F., Dumbardon-Martial E., Ramage T., Lucas P.D., RoME D. 2018. Inventaire entomologique des ZNIEFF de Martinique Campagne de terrain 2017. Rapport SEAG 2018-1. Mscr.

WigGins G.B. 1983. Entomology and society. Bulletin Entomology Society of America, 29 (1): $27-30$.

Received: 31 January 2019

Accepted: 6 June 2019 